\title{
DOKTRIN PERTANGGUNGJAWABAN KOMANDO ATAS KEJAHATAN BERAT HAM MENURUT HUKUM PIDANA INTERNASIONAL
}

\author{
oleh: \\ Ryan Fani
}

\begin{abstract}
Kejahatan berat Hak Asasi Manusia (HAM) dalam skala Internasional meliputi Kejahatan Genosida, Kejahatan terhadap kemanusiaan, Kejahatan Perang dan Kejahatan Agresi. Kejahatan berat HAM ini biasanya dijadikan sebagai alat pencapaian dari kebijakan kebijakan pemerintah, sehingga kejahatan ini mempunyai kaitan erat dengan peran pimpinan militer maupun pimpinan sipil yang mempunyai motivasi tertentu seperti pemberian perintah untuk melakukan kejahatan berat HAM terhadap anak buahnya. Oleh karenanya hal itu akan sangat berhubungan dengan doktrin Pertanggungjawaban Komando, doktrin pertanggungjawaban komando dalam tatanan hukum internasional mempunyai penafsiran yang kurang tegas dan luas yang rentan menimbulkan rasa ketidakadilan dalam pelaksanaan penegakan hukum. Metode yang digunakan dalam artikel ini adalah metode yuridis normatif dengan menggunakan data sekunder. Hasil penelitian yang didapatkan ialah ketidak tegasan dari prinsip atau doktrin pertanggungjawaban komando terdapat pada redaksi atau frasa "Ketidak-berhasilan Komandan". frasa tersebut dapat ditafsirkan bahwa walaupun komandan/atasan telah melakukan upaya pengendalian semaksimal mungkin terhadap anak buahnya yang akan, sedang, atau telah melakukan kejahatan berat HAM, namun upaya tersebut tetap tidak berhasil dan pada faktanya anak buahnya telah melakukan kejahatan, maka atasan dimaksud dapat dipertanggungjawabkan, namun disisi lain frasa "ketidakberhasilan" ini juga dapat ditafsirkan atas tindakan komandan/atasan yang melakukan pembiaran (ommision), artinya komandan atau atasan sama sekali tidak melakukan upaya pengendalian (Pencegahan atau tindakan) terhadap bawahan atau anak buahnya, atas dasar hal itu maka sikap atasan dimaksud dapat dipertanggungjawabkan. Ketidak tegasan prinsip atau doktrin inilah yang kemudian akan menimbulkan ketidak adilan bagi para pihak yang bersangkutan, sehingga perlu adanya pembaharuan penafsiran secara tegas atas doktrin pertanggungjawaban komando ini.
\end{abstract}

Kata Kunci: Kejahatan Berat HAM, Doktrin Pertanggungjawaban Komando, Hukum Pidana Internasional

\section{PENDAHULUAN}

\section{A. Latar Belakang}

Kejahatan internasional dapat dikategorikan sebagai kejahatan berat, karena didalamnya melibatkan beberapa negara dan sebagian besar jenis kejahatan yang dilakukan dinilai kurang manusiawi, sehingga menjadi perhatian utama bagi masyarakat internasional di beberapa negara lainnya. Kejahatan - kejahatan internasional yang dikategorikan sebagai kejahatan berat adalah kejahatan yang menyangkut pelanggaran Hak Asasi Manusia (HAM).

Kejahatan - Kejahatan berat HAM tersebut meliputi Kejahatan Genosida, Kejahatan terhadap Kemanusiaan, Kejahatan Perang dan Kejahatan Agresi. Kesemua kejahatan dimaksud sering terjadi dalam skala internasional, misalnya dalam perang dunia II, terkait perkara di Nuremberg dan Tokyo, begitu juga dalam perkara di Rwanda dan Yugoslavia, kejahatan yang terjadi dalam perkara - perkara tersebut dapat disebut dan/atau dikategorikan sebagai pelanggaran - pelanggaran HAM berat.

Kejahatan berat HAM dalam skala Internasional adalah hal yang esensial dan wajib hukumnya untuk dilakukan penegakan dari berbagai aspek karena hal itu telah menyangkut nilai - nilai kemanusiaan. Terjadinya kejahatan - kejahatan berat HAM dalam skala Internasional dimaksud tentunya tidak akan terlepas dari peran para militer maupun sipil disuatu negara yang mempunyai 
motivasi - motivasi tertentu, hal mana peran - peran tersebut juga didalangi oleh para pimpinan pimpinannya.

Bahwa para pimpinan militer maupun pimpinan sipil dan/atau pimpinan politik disuatu negara yang mempunyai peran secara tidak langsung dalam terjadinya kejahatan berat HAM di skala internasional, seperti melakukan tindakan pembiaran (ommision) atas terjadinya kejahatan perang, terkadang atas dasar hal itu juga Komandan atau atasan sipil berlindung dibalik perbuatan - perbuatan para anak buahnya sendiri, artinya pimpinan mempunyai alasan jitu agar dirinya tidak dapat dipersalahkan, salah satunya adalah dengan lebih menekankan dan menyalahkan bahwa anak buahlah yang bertindak atas kehendak sendiri dan bertindak diluar dari komando atasannya.

Padahal diketahui bahwa dalam terjadinya kejahatan HAM skala Internasional, sangat berlaku prinsip atasan bertanggungjawab penuh terhadap bawahannya, karena kendali atas perilaku anak buah berada pada atasan, baik terhadap pimpinan militer maupun terhadap pimpinan sipil sekalipun. Sehingga jika ternyata anak buah melakukan kejahatan diluar kendali atasan dan atasan lalai atau gagal mencegah kejahatan dimaksud, maka sesuai dengan prinsip pertanggungjawaban komando, pimpinan wajib bertanggung jawab secara pidana atas perbuatan anak buahnya dimaksud. Doktrin pertanggungjawaban komando dalam tatanan hukum internasional mempunyai penafsiran yang kurang tegas dan luas yang rentan menimbulkan rasa ketidakadilan dalam pelaksanaan penegakan hukum, sehingga atas dasar hal tersebut penulis sangat tertarik untuk membahas lebih dalam dan terperinci tentang penerapan dan penafsiran doktrin pertanggungjawaban komando dalam ketentuan hukum Pidana Internasional.

Instrumen - instrumen hukum internasional dituntut memberlakukan Doktrin/konsep pertanggungjawaban komando tersebut untuk dapat memeriksa dan mengadili perkara - perkara kejahatan berat HAM dalam skala Internasional. Pertanyaanya adalah seberapa penting pertanggungjawaban komando ini wajib untuk diberlakukan dalam instrumen hukum Internasional, apa pertimbangan utama dalam memberlakukan pertanggungjawaban komando dimaksud, lalu bagaimana konsep atau doktrin pertanggungjawaban komando secara rinci dalam ketentuan ketentuan hukum Internasional dimaksud, apakah benar - benar didasarkan atas ketidakberhasilan komandan/atasan sipil dalam melakukan upaya pengendalian anak buahnya, ataukah didasarkan atas tindakan komandan yang sama sekali tidak melakukan pengendalian terhadap anak buahnya yang akan, atau sedang melakukan kejahatan. Tentunya permasalahan - permasalahan ini baik secara substansi maupun dalam penerapan penegakan hukumnya akan sangat berkaitan dengan rasa keadilan.

Berdasarkan hal - hal tersebut maka penulis mengusung artikel yang berjudul "Doktrin Pertanggungjawaban Komando atas Kejahatan Berat HAM menurut Hukum Pidana Internasional". Hal mana didalamnya tersebut akan memuat unsur tentang pengertian pertanggungjawaban komando, memuat unsur tentang Kategori Kejahatan berat HAM dalam lingkup Internasional, lalu memuat unsur tentang tujuan serta pemberlakuan Konsep/Doktrin pertanggungjawaban komando dalam ketentuan - ketentuan hukum Pidana internasional yang ditujukan terhadap perkara - perkara berat HAM Internasional dan dalam artikel ini juga akan dimuat sedikit kritik terhadap pemberlakuan konsep tersebut.

\section{B. Identifikasi Masalah}

1. Apa yang dimaksud dengan Definisi dan Pengertian pertanggungjawaban Komando dalam lingkup kejahatan Internasional ?

2. Bagaimana tujuan dan konsep pemberlakuan doktrin pertanggungjawaban komando atas kejahatan berat HAM dalam Hukum Pidana Internasional ?

\section{Metode}

Penelitian ini menggunakan metode penelitian dengan mengimplementasi bahan pustaka atau data sekunder belaka terhadap peristiwa hukum tertentu yang terjadi dalam suatu masyarakat. Metode pendekatan dalam penelitian ini dapat dinamakan sebagai metode penelitian Yuridis Normatif. 


\section{PEMBAHASAN}

\section{A. Definisi dan Pengertian Pertanggungjawaban Komando}

Konsep pertanggungjawaban komando, mempunyai makna yang sangat luas, artinya konsep ini tidak terbatas dan berlaku bagi setiap pemangku jabatan dan/atau setiap atasan yang mempunyai kendali atas anak buahnya, sekalipun itu adalah kepala negara, kepala pemerintahan, menteri, pimpinan militer maupun pimpinan perusahaan. Kesemuanya dibebani tanggungjawab atas perbuatan yang dilakukan oleh anak buahnya.

Dalam hukum internasional pertanggungjawaban komando ini dianggap sebagai perluasan dari pertanggungjawaban Individu (Individual Resposibility). Konsep pertanggungjawaban ini sering diberlakukan terhadap kejahatan - kejahatan berat Hak Asasi Manusia, khususnya dalam perkara perkara setelah perang dunia II, perihal kejahatan perang yang dianggap sebagai kejahatan Internasional.

Bentuk tanggung jawab komando ini berbeda dengan bentuk pertanggungjawaban pidana secara individu yang dapat dikenakan kepada komandan atau atasan apabila ia ikut merencanakan, menghasut, memerintahkan, membantu, melakukan, dan turut serta melakukan kejahatan. Apabila komandan melakukan dari salah satu tindakan seperti tersebut di atas, maka komandan telah melakukan tindakan penyertaan (joint criminal enterprise) dan statusnya disamakan dengan pelaku langsung. ${ }^{1}$

Menurut hemat penulis bahwa konsep pertanggungjawaban komandan (commander responsibility), dapat dipersamakan dengan kelalaian dari komandan yang sama sekali tidak melakukan pengendalian terhadap anak buahnya dan/atau mencegah anak buahnya melakukan kejahatan, khususnya kejahatan dalam skala internasional, sehingga mewajibkan komandan bertanggung jawab secara pidana. Sebenarnya komandan dalam konsep ini hanya berperan pasif atas terjadinya suatu kejahatan, sehingga pertanggungjawaban dimaksud hanya dapat disebut sebagai perluasan dari tanggung jawab individu saja dan tidak dapat dianggap sebagai konsep pertanggungjawaban individu seutuhnya, karena pada hakikatnya dalam konsep pertanggungjawaban individu pelaku akan berperan aktif dan terlibat langsung dalam merencakan serta melakukan kejahatan.

Hal itu sejalan dengan salah satu referensi yang menyatakan bahwa doktrin tanggung jawab komando didefinisikan sebagai tanggung jawab komandan militer terhadap kejahatan perang yang dilakukan oleh prajurit bawahannya atau orang lain yang berada dalam pengendaliannya. ${ }^{2}$ Jadi, tanggung jawab komando yang diatur dalam hukum perang berkaitan dengan tanggung jawab pidana seorang komandan (Commander criminal responsibility) dan bukan tanggung jawab umum dari suatu pemegang komando (general responsibility of command). ${ }^{3}$

Berdasarkan definisi mengenai tanggung jawab komando di atas maka subyek yang harus bertanggung jawab adalah komandan militer. Akan tetapi dalam praktek dan perkembangannya, doktrin tanggung jawab komando bukan hanya diberlakukan para komandan militer saja tetapi juga terhadap atasan atau penguasa sipil yang memiliki kewenangan untuk memberikan komando atau perintah kepada pejabat militer atau menggerakkan kekuatan militer. Berdasarkan hal tersebut maka muncullah istilah tanggung jawab atasan (superior responsibility) disamping tanggung jawab komandan (commander responsibility). ${ }^{4}$

Pada prinsipnya pertanggungjawaban komando awal mulanya hanya diperuntukan bagi kejahatan perang, namun pada praktik dan perkembangannya, konsep ini juga menjadi tidak terbatas, hal mana konsep ini mencakup kejahatan terhadap kemanusiaan dan/atau terhadap pelanggaran pelanggaran berat HAM lainnya yang diatur dalam beberapa instrumen hukum internasional.

\footnotetext{
${ }^{1}$ International Law Commision, Draft Article on Responsibility of statesfor Internationally Wrongful Act Adopted by the drafting Committee on Second Reading, Geneva 2001, dalam Pasal11 Control Council No.10

2 Weston D. Burnett, Command Responsibility and Acase Study of the Criminal Responsibility of Israel Military Commanders for the Progrom at Shatila and Sabra, 107 Military Law Review, 1985, hal.76.

${ }^{3}$ Natsri Anshari, Dalam Artikel Tanggung Jawab Komando Menurut Hukum Internasional dan hukum nasional Indonesia, Jurnal Hukum Humaniter Vol.1 No.1, Edisi Juli 2005, Pusat Studi Hukum Humaniter Dan HAM (terAS) Fakultas Hukum Universitas TRISAKTI, hal.48

${ }^{4}$ Vonny A Wongkar, Op.Cit, hlm. 53
} 
Berdasarkan hal tersebut maka saat ini dalam perkembangannya konsep pertanggungjawaban komando, dikenal dua jenis, yang mana jenis konsep tersebut adalah pertanggungjawaban komandan (commander resposibility) dan pertanggungjawaban atasan (Superior Responsibility). Keduanya merupakan hal yang berbeda.

Perbedaan yang paling mendasar ialah, dalam Commander Resposibility yang menjadi subyeknya adalah Komandan Militer, sedangkan dalam Superior Responsibility yang menjadi subyeknya adalah atasan atau penguasa sipil, seperti Kepala Negara, Menteri, pimpinan - pimpinan perusahaan dan lain - lain.

Selain dari itu, perbedaan dari aspek lainnya adalah superior responsibility berkaitan dengan pemidanaan terhadap komandan apabila memerintahkan anak buah/bawahan melakukan kejahatan perang. Sedangkan command responsibility adalah dasar pemidanaan terhadap para komandan/atasan apabila anak buah/bawahan yang berada di bawah komando dan pengendaliannya terlibat kejahatan pada waktu pelaksanan tugas. ${ }^{5}$

Penulis menyimpulkan bahwa dalam konsep Superior Responsibility, selain daripada konsep kelalaian dan/atau kegagalan atasan dalam mengendalikan anak buah, dalam konsep ini atasan juga dimungkinkan mempunyai peran aktif, artinya penguasa atau atasan atau pimpinan sipil terlibat langsung dalam perencanaan maupun dalam hal pemberian instruksi atau perintah terhadap anak buahnya untuk melakukan kejahatan - kejahatan Internasional (Kejahatan berat HAM), lain hal nya dengan Commander Responsibility/pertanggungjawaban komandan sebagaimana yang telah dijelaskan di atas bahwa dalam konsep ini, seutuhnya komandan atau atasan tidak berperan aktif, hal mana komandan dimaksud didapati telah lalai dan/atau tidak melakukan tindakan - tindakan apapun dalam melakukan pencegahan terhadap anak buah yang akan atau sedang melakukan kejahatan, sehingga terjadi pembiaran (ommision).

Bahwa sebenarnya konsep pertanggungjawaban komando yang sebagian besar diberlakukan dan dikenal dalam beberapa instrumen hukum internasional maupun domestik khususnya di negara Indonesia, adalah konsep pertanggungjawaban komandan/ commander Responsibility, hal mana pimpinan atau komandan berperan pasif, komandan lalai dan/atau sama sekali tidak melakukan pengendalian terhadap perilaku anak buahnya yang akan atau sedang melakukan kejahatan Internasional, hal mana itu semua dapat dipersamakan sebagai tindakan pembiaran atas terjadinya kejahatan internasional.

\section{Kejahatan Berat HAM menurut Hukum Internasional}

Kejahatan berat HAM dalam tatanan hukum internasional merupakan salah satu kejahatan yang dikategorikan sebagai extraordinary crime, karena sebagian besar kejahatan - kejahatan yang dilakukan tersebut dianggap tidak manusiawi, sehingga perlu adanya penegakan hukum yang tegas terhadap kejahatan berat HAM dimaksud.

Pasca berakhirnya Perang Dunia II memberikan dampak yang luar biasa di hadapan masyarakat internasional. Hukum Internasional Hak Asasi Manusia mengalami perkembangan yang pesat dan signifikan dengan sendirinya yang menjadi rujukan berbagai aktor seperti negara, organisasi internasional, masyarakat internasional dan individu ketika menanggapi banyak peristiwa pelanggaran Hak Asasi Manusia. Kejahatan berat hak asasi manusia atau sebutan lain pelanggaran HAM berat dalam hukum internasional berkaitan dengan beberapa ketentuan yang berkembang pasca perang dunia kedua, yang dapat dilihat dalam Pengadilan Nuremberg yang meliputi genocide, War Crime, Crime Against Humanity, diatur dalam International Criminal Tribunal for the former Yugoslavia(ICTY) dan International Criminal Tribunal for Rwanda (ICTR) yang meliputi War crimes, Crimes against humanity, dan Genocide. ${ }^{6}$

Istilah Kejahatan berat HAM telah dikenal dan digunakan pada saat ini belum dirumuskan secara jelas, baik di dalam resolusi, deklarasi maupun perjanjian HAM. Kejahatan berat HAM

\footnotetext{
${ }^{5}$ Sihombing, dalam makalah, Perintah Atasan dan pertanggungjawaban Komando dalam Kejahatan Perang, dalam seminar "Problematika Kejahatan Perang dalam hukum Pidana Indonesia", yang diselenggarakan oleh Pusat kajian HAM dan Hukum Humaniter UNISBA-The International Committee of The Red Cross (ICRC), Bandung 2005. Hal.3

6 Penulisan Hukum tentang Pengaturan Pelanggaran Kejahatan HAM Berat Menurut Hukum Internasional dalam http://repository.usu.ac.id/bitstream/123456789/48857/3/Chapter\%20II.pdf
} 
dipahami sebagai suatu perbuatan pelanggaran HAM yang membawa dampak buruk yang luar biasa dahsyat pada jiwa, raga dan peradaban manusia. ${ }^{7}$

Cecilia Meidina Quiroga menjelaskan istilah Pelanggaran HAM Berat sebagai suatu pelanggaran yang mengarah kepada pelanggaran-pelanggaran, sebagai alat bagi pencapaian dari kebijakan-kebijakan pemerintah, yang dilakukan dalam kualitas tertentu dalam suatu cara untuk menciptakan situasi hak untuk hidup, hak atas integritas pribadi atau hak atas kebebasan pribadi dari penduduk suatu Negara secara terus menerus yang dilanggar atau diancam. Menurut Peter Baehr, pelanggaran berat hak asasi manusia akan menyangkut masalah-masalah yang meliputi the prohibiton of slavery, the right to life, torture and cruel, inhuman or degrading treatment or punishment, genocide, dissappearences and ethnic cleansing. ${ }^{8}$

Definisi dan kategori dari Kejahatan berat HAM juga disebutkan di dalam Piagam Pengadilan Militer Internasional Nuremberg sebagai salah satu peradilan ad hoc Internasional, yang pada hakikatnya menjelaskan sebagai berikut: ${ }^{9}$

1. Kejahatan terhadap perdamaian (Crimes against peace). Termasuk kejahatan terhadap perdamaian ialah: merencanakan, mempersiapkan, memulai, atau menjalankan perang agresi, atau perang yang melanggar perjanjian-perjanjian internasional, persetujuan-persetujuan atau jaminanjaminan; atau turut serta di dalam rencana bersama atau komplotan untuk mencapai salah satu daripada tujuan perbuatan-perbuatan tersebut di atas.

2. Kejahatan Perang (War Crimes). Yang termasuk dalam kejahatan perang ialah: pelanggaran terhadap hukum atau kebiasaan-kebiasaan perang, seperti pembunuhan (murder), perlakuan kejam terhadap penduduk sipil dengan mengasingkan mereka, memberlakukan kerja paksa, atau di wilayah pendudukan memperlakukan tawanan-tawanan perang dengan kejam, membunuh, atau memperlakukan orang yang berada di laut secara demikian; merampas milik negara atau milik perseorangan, menghancurkan kota atau desa dengan berlebihan atau semena-mena, atau membinasakannya tanpa adanya keperluan militer.

3. Kejahatan terhadap Kemanusiaan (Crimes against humanity). Yang termasuk kejahatan terhadap kemanusiaan ialah: pembunuhan (murder) membinasakan, memperbudak, mengasingkan dan lain-lain kekejaman di luar perikemanusiaan terhadap penduduk sipil, yang dilakukan sebelum atau sesudah perang; perkosaan hak-hak dasar berdasarkan alasan-alasan politik, ras atau agama. Pemimpin atau orang yang mengorganisir, menghasut dan membantu mereka yang turut serta dalam membentuk atau melaksanakan rencana bersama komplotan untuk melakukan kejahatankejahatan tersebut bertanggungjawab atas perbuatan orang-orang yang melakukan rencana tersebut.

Selain tersebut dalam salah satu piagam peradilan ad hoc internasional di atas, definisi dan kategori Kejahatan berat HAM dalam skala Internasional ini juga telah dijelaskan dalam statuta Mahkamah Pidana Internasional atau sering dikenal dengan istilah International Criminal Court (ICC), dalam statuta ICC kejahatan yang dikategorikan sebagai kejahatan berat HAM terdiri dari: ${ }^{10}$

1. Kejahatan genosida

2. Kejahatan terhadap kemanusiaan

3. Kejahatan perang

4. Kejahatan agresi.

Berdasarkan penjelasan - penjelasan tersebut di atas, maka dapat ditarik suatu kesimpulan, bahwa Kejahatan berat HAM merupakan kejahatan yang mempunyai kualitas kejahatan yang sangat tinggi dan mempunyai dampak buruk bahkan berdampak luar biasa dahsyat terhadap jiwa, raga, dan peradaban manusia, selain daripada itu dalam berbagai kasus yang ditemui, kejahatan berat HAM biasanya dilakukan sebagai alat bagi pencapaian dari kebijakan-kebijakan pemerintah.

Kejahatan berat HAM yang dikategorikan dalam skala Internasional berdasarkan penjelasan penjelasan di atas yang dihimpun dalam beberapa Instrumen Hukum Internasional, maka penulis dapat

\footnotetext{
7 Ibid.,

${ }^{8}$ Andrey Sujatmoko,Tanggung Jawab Negara atas Pelanggaran Berat Hak Asasi Manusia. Indonesia, Timor Leste, dan lainnya, Gramedia Widiasarana Indonesia, 2005, hlm. 71 mengutip Cecilia MedinaQuiroga, The battle of Human Rights; Gross, Systematic Violation and the inter American system, Dordrech/Boston/London: Martinus Nijhoff Publishers, 1988, page. 16.

${ }^{9}$ Pasal 6 Piagam Peradilan Militer Internasional Nuremberg.

${ }^{10}$ Pasal 5 Statuta Roma tahun 1998
} 
menyimpulkan bahwa kejahatan berat HAM terbagi ke dalam 4 Kategori yakni: Kejahatan terhadap perdamaian yang didalamnya memuat kejahatan agresi, Kejahatan Genosida, Kejahatan terhadap kemanusiaan, dan kejahatan perang.

Sebagaimana yang telah dijelaskan sebelumnya di atas, bahwa Kejahatan HAM khususnya yang berskala Internasional, wajib untuk ditegakan melalui upaya represif berupa penegakan hukum, tentunya melalui instrumen hukum internasional penegakan hukum kejahatan berat HAM dapat terealisasi dengan baik dan teratur.

Instrumen internasional merupakan alat yang berupa standar-standar pembatasanpelaksanaan dan mekanisme kontrol terhadap kesepakatan kesepakatan antar negara tentang jaminan HAM.Oleh karena dibutuhkan adanya pembatasan untuk melindungi HAM maka dibuat lah beberapa instrumen hukum internasional yang berlaku universal terbentuk atas kesepakatan antar negara sehingga dapat menjadi pedoman bagi suatu negara dalam menghukum pelaku kejahatan tersebut.

Kejahatan berat HAM yang terjadi baik dalam skala nasional maupun internasional, setiap negara tentunya dapat menganut beberapa instrumen - instrumen hukum internasional sebagai pedoman untuk menegakan dan menyelesaikan kejahatan berat HAM. Beberapa Instrumen hukum internasional yang berkaitan dengan Kejahatan berat HAM diantaranya:

1. Deklarasi Universal tentang Hak - Hak Asasi Manusia tahun 1948;

2. Charter of The United Nation (Piagam PBB) pada tahun 1945;

3. Konvensi - Konvesi Jenewa dan Protokolnya pada tahun 1949.

Penulis hanya menyebutkan tiga instrumen saja dikarenkan Ketiga Instrumen Hukum Internasional tersebut adalah Instrumen yang sering ditemui dan digunakan sebagai pedoman oleh beberapa negara dalam melakukan upaya preventif maupun rerpesif atas suatu kejahatan berat HAM dan bahkan tak sedikit beberapa negara yang mengadopsi ketentuan - ketentuan hukum internasional dimaksud ke dalam hukum domestiknya sendiri, sebenarnya sangat banyak instrumen - instrumen hukum internasional yang mengatur mengenai Kejahatan berat HAM, namun dalam hal ini penulis hanya menyebutkan instrumen yang lebih banyak dibahas oleh beberapa pratiksi maupun akademisi hukum, seperti halnya ketiga instrumen hukum di atas.

\section{B. Doktrin Pertanggungjawaban Komando atas Kejahatan berat HAM menurut Hukum Pidana Internasional}

Doktrin Pertanggung jawaban komando sudah dikenal sejak tahun 1439 ketika Charles VII dari Perancis mengeluarkan perintah di Orleans yang menyatakan: ${ }^{11}$

"The King orders that each captain or lieutenant be held responsible for the abauses. Ills and offences committed by members of his company, and that as soon as he receives any complaint concerning any such misdeed or abuse, he bring the offender to justice so that the said offender be punished in a manner commensurate with his offence. If he fails to do so or covers up the misdeed or delays taking action, or if, because of his negligence or otherwise, the offender escapes and thus evades punishment, the capatain shall be deemed responsible for the offence as if he had committed it himself and shall be punished in the same way as the offender would have been ".

Pada hakikatnya perintah tersebut mempunyai makna sebagai berikut; setiap kapten atau letnan bertanggungjawab atas anggotanya, jika terdapat kelakuan buruk atau suatu penyalahgunaan yang didapati dari anggotanya, ia wajib membawa pelaku ke Pengadilan agar dihukum sepadan dengan pelanggaran yang telah diperbuatnya. Jika ia gagal melakukannya atau menutupi kelakukan buruk dan/atau melakukan penundaan dalam mengambil suatu tindakan dan/atau karena kelalaiannya pelaku lolos dan terhindar dari hukuman, maka kapten bertanggungjawab atas pelanggaran yang dilakukan oleh anggotanya dimaksud, kapten seolah - olah dianggap melakukan pelanggaran dan harus dihukum dengan cara yang sama seperti pelaku utamanya yang dalam hal ini adalah anggotanya.

Prinsip tanggung jawab komando tersebut juga terdapat dalam ketentuan - ketentuan mengenai Perang (the Article of War) yang dikeluarkan oleh Gustavus Adolphus dari Swedia pada tahun 1621 yang menyebutkan : "Seorang Kolonel atau Kapten tidak boleh memerintahkan prajuritnya untuk melakukan tindakan yang melanggar hukum, barang siapa yang memerintahkan yang demikian itu, harus dihukum menurut putusan hakim (No Colonel or Captain shall command his solidiers to do any unlawful thing, which who so does, shall be punished according to the discretion of the Judges) ".

\footnotetext{
${ }^{11}$ Burhan dahlan, Tanggung Jawab Komando dalam Hukum Humaniter Internasional, Penulisan Hukum, 2011,
} 
Demikian juga Hugo Grotius menyatakan “ Bahwa Negara dan Pejabat yang berkuasa bertanggung jawab terhadap kejahatan yang dilakukan oleh orang yang berada di bawah kekuasaannya, jika mereka mengetahui dan tidak melakukan pencegahan padahal mereka dapat dan harus melakukan hal itu ". ${ }^{12}$

Di era tahun 1900 - an Pengaturan Prinsip tanggungjawab komando ini terdapat dalam salah satu ketentuan hukum Internasional yaitu Konvensi Den Haag IV 1907 tentang Hukum dan Kebiasaan Perang di Darat yang secara khusus diatur di Pasal 3. Dalam ayat (1) dari Pasal 3 Konvensi Den Haag IV 1907 ini mengatakan bahwa setiap pihak yang bersengketa yang melanggar ketentuan hukum perang bertanggung jawab untuk membayar kompensasi jika kasusnya menghendaki demikian. Kemudian ayat (2) dari pasal yang sama mengatur bahwa pihak yang bersengketa bertanggung jawab terhadap setiap tindakan yang dilakukan oleh anggota angkatan bersenjatanya. Dari ketentuan Pasal 3 Konvensi Den Haag IV 1907 ini dapat disimpulkan adanya konsep pertanggungjawaban Komando, meskipun tidak secara spesifik menunjuk pada seseorang komandan. ${ }^{13}$

Bahwa setelah perang dunia ke - II, Doktrin tanggung jawab Komando ini semakin berkembang, terutama dalam melakukan penegakan hukum atas kejahatan berat HAM, hal tersebut dapat dilihat dari sejarah dibentuknya Pengadilan Nuremberg dan Pengadilan Tokyo sebagai Pengadilan Internasional ad hoc, saat itu para pelaku kejahatan perang NAZI dan Jepang diadili di kedua pengadilan dimaksud. Pengadilan Nuremberg dibentuk berdasarkan Piagam London pada tahun 1945 dan Pengadilan Tokyo dibentuk berdasarkan Proklamasi Komandan Tertinggi Pasukan Sekutu Jenderal Douglas Mac Arthur pada tahun 1946 yang selebihnya diatur dalam Piagam Pengadilan Tokyo. Kedua pengadilan ad hoc ini mempunyai yurisdiksi untuk mengadili kejahatan terhadap perdamaian, Kejahatan Perang dan Kejahatan terhadap Kemanusiaan, yang keseluruhannya adalah termasuk sebagai kategori Kejahatan berat HAM.

Dengan melihat kedua mahkamah Nurember serta Tokyo, dapat dijelaskan bahwa apabila terjadi suatu kejahatan maka tanggung hawab berlaku bagi para pemimpin, organisator, pemicu dan penyerta yang ikut serta dalam merumuskan atau melaksanakan rencana umum atau konspirasi serta untuk melakukan setiap kejahatan. Baik pihak yang memberi perintah dan yang melaksanakan perintah sama - sama bersalah melaksanakan kejahatan. Apabila komandan yang bersangkutan tidak memerintahkan (memberi perintah secara langsung) kejahatan tersebut tetapi ia mengetahui atau semestinya mengetahui tindakan yang melanggar hukum dan tidak mengambil tindakan yang seestinya maka komandan tersebut dapat dihukum. ${ }^{14}$

Kemudian pada tahun 1949, Prinsip dan/atau doktrin tanggung jawab komando ini juga dijelaskan dalam Pasal 86 dan Pasal 87 Protokol tambahan I Konvensi Jenewa 1949 dan 1977. Pasal 86 memberlakukan tanggungjawab terhadap semua atasan atas kegagalannya untuk mencegah dan menindak tindak pidana yang dilakukan oleh anak buahnya. Sedangkan dalam Pasal 87 memberlakukan tugas khusus bagi komandan militer berdasarkan kewenangannya untuk melakukan pengendalian. ${ }^{15}$

Akar dari doktrin ini dapat ditelusuri melalui sejarah kemiliteran dimana syarat untuk menempatkan tanggung jawab yang paling besar ada di tangan komandan militer. ${ }^{16}$ Dasar hukum bagi komandan militer atau individu lain yang berada dalam posisi atasan atau pemegang kekuasaan komando lainnya untuk bertanggung jawab secara pidana atas kelalaian atau kegagalannya untuk melaksanakan pengendalian terhadap anak buahnya sehingga terjadi kejahatan internasional. kegagalan bertindak (failure to act) ini dikatakan sebagai tindakan pembiaran (ommision) sehingga komandan harus bertanggungjawab. ${ }^{17}$

Bahwa selain daripada pengadilan Nuremberg dan Pengadilan Tokyo sebagaimana yang telah dipaparkan sebelumnya di atas, ditahun 1993 dan 1994 prinsip pertanggungjawaban Komado ini juga dijelaskan dalam ketentuan International Criminal Tribunal For The Former Yugoslavia (ICTY) dan International Criminal Tribunal For Rwanda (ICTR) sebagai Pengadilan Internasional Ad Hoc. ICTY

\footnotetext{
12 Ibid.,

13 Fadillah Agus, makalah Tanggungjawab Komando, dalam Seminar "Judging international Crimes under law 26/2000, Mahkamah Agung RI-Danish Institute for human Rights, Medan 24 - 26 April 2005

${ }^{14}$ Hidayat Muhtar, dalam Penulisan hukum, Kajian Yuridis terhadap Asas Pertanggungjawaban Komando.

15 Vonny A Wongkar, Tanggung Jawab Komando terhadap Pelanggaran Hak Asasi Manusia (HAM) yang berat dan Kejahatan Perang dalam Pembaharuan Hukum Pidana di Indonesia, Thesis, FH UNDIP, 2006, hal. 63

${ }^{16}$ Ibid., hal. 51

${ }^{17}$ ELSAM, Makalah Tanggung Jawab Komando
} 
dibentuk melalui resolusi Dewan Keamanan PBB pada tahun 1993 dan ICTR dibentuk melalui resolusi Dewan Keamanan PBB pada tahun 1994, keduanya dibentuk untuk mengadili para pelaku kejahatan genosida, kejahatan terhadap kemanusiaan maupun kejahatan berat HAM lainnya yang terjadi di Rwanda maupun di Negara - Negara Bekas Yugoslavia.

Dalam ICTY prinsip tanggung jawab Komando diatur dalam Pasal 7 ayat (3) Statuta ICTY, yang pada hakikatnya menegaskan bahwa seorang komandan dapat dikenakan tanggung jawab mengenai kejahatan yang dilakukan oleh prajuritnya yang berada dibawah komandonya jika ia memerintahkan, atau menyadari atau memiliki alasan untuk mengetahui bawahannya akan melakukan kejahatan serta ia gagal untuk mengambil langkah yang diperlukan dan pantas guna mencegahnya. Hal yang sama juga dipertegas dalam Pasal 6 ayat (3) Statuta ICTR. ${ }^{18}$

Selain daripada Pengadilan Ad Hoc Internasional dan beberapa ketentuan - ketentuan hukum Internasional sebagaimana yang telah dijelaskan sebelumnya di atas, Pengadilan Pidana Internasional Permanen yaitu International Criminal Court (ICC) / Mahkamah Pidana Internasional di era zaman sekarang, adalah ketentuan hukum internasional yang menjadi acuan utama bagi negara - negara diseluruh penjuru dunia dalam rangka melakukan penegakan hukum atas kejahatan berat HAM.

Pada tanggal 17 Juli 1998 Statuta Roma, International Criminal Court (ICC) telah disahkan untuk mengadili kejahatan Genosida, Kejahatan terhadap kemanusiaan, kejahatan perang dan agresi. Sekitar 120 negara telah menandatangani statuta tersebut waktu itu, 6 menolak dan 10 abstain, termasuk indonesia. Untuk berlakunya ICC secara resmi diperlukan ratifikasi atau instrumen lainnya dari 60 Negara peserta yang diserahkan ke Sekretaris Jenderal PBB. ${ }^{19}$

Sebagaimana yang telah dijelaskan di atas salah satu tujuan dibentuknya ICC adalah untuk melakukan penegakan hukum terhadap pelaku kejahatan berat HAM dalam skala internasional, Jika dihubungkan dengan poin penting dari pembahasan ini, salah satu implementasi penegakan hukum Kejahatan berat HAM dalam ICC adalah adanya pemberlakuan prinsip pertanggungjawaban komando terhadap pelaku kejahatan dalam lingkup internasional, khususnya dalam kejahatan berat HAM.

Prinsip pertanggungjawaban komando pada ICC diatur dalam Pasal 28 huruf a yang pada hakikatnya menyatakan bahwa seorang komandan militer atau orang yang secara efektif bertindak sebagai komandan militer bertanggung jawab secara pidana atas kejahatan yang berada dalam yurisdiksi Pengadilan yang dilakukan oleh pasukan yang berada di bawah komando dan kendalinya secara efektif, sebagai akibat kegagalannya dalam menjalankan pengendalian yang semestinya terhadap pasukan tersebut, dalam hal: ${ }^{20}$

1. Bahwa komandan militer mengetahui atau berdasarkan keadaan yang berlangsung saat itu, mesti telah mengetahui bahwa pasukannya sedang melakukan atau akan melakukan kejahatan.

2. Bahwa komandan militer tidak berhasil mengambil semua tindakan yang semestinya dan diperlukan sesuai kewenangannya untuk mencegah atau menindak terjadinya kejahatan atau mengajukan pelanggaran tersebut kepada lembaga yang berwenang dibidang penyelidikan dan penuntutan.

Berkaitan dengan hubungan atasan dan bawahan yang tidak tercakup dalam pasal di atas, pasal 28 huruf (b) menyatakan seorang atasan bertanggung jawab secara pidana atas kejahatan yang berada dalam yurisdiksi Pengadilan yang dilakukan oleh bawahan yang berada di bawah kekuasaan dan kendali efektifnya, sebagai akibat kegagalannya dalam menjalankan pengendalian yang semestinya terhadap bawahan tersebut, dalam hal:

1. Atasan mengetahui, atau secara sadar mengabaikan informasi yang dengan jelas mengindikasikan bawahannya sedang melakukan atau akan melakukan kejahatan.

2. Kejahatan tersebut berkaitan dengan kegiatan-kegiatan yang berada dalam tanggung jawab dan pengendalian atasan secara efektif.

3. Atasan gagal mengambil semua upaya yang semestinya dan diperlukan sesuai kewenangannya untuk mencegah dan menindak terjadinya kejahatan atau mengajukan

\footnotetext{
18 Hidayat Muhtar, Op.Cit.

19 Eddy Djunaedi Karnasudirdja, dari Pengadilan Militer Internasional Nuremberg ke Pengadilan Hak Asasi Manusia Indonesia, Jakarta, Tatanusa, 2003, hlm. 53

${ }^{20}$ Diambil dari lampiran Romli Atmasasmita, Pengantar Hukum Pidana Internasional, Bandung, Refika Aditama, 2003, hal 96.
} 


\section{pelanggaran tersebut kepada lembaga yang berwenang di bidang penyelidikan dan penuntutan.}

Jika dilihat secara seksama Konsep dari pertanggungjawaban komando dalam ICC di atas, dalam Pasal 28 huruf a memuat konsep tanggung jawab komandan (commander responsibility) artinya yang menjadi subyek dalam huruf a Pasal dimaksud adalah Komandan Militer dan untuk Pasal 28 huruf b, memuat konsep tanggung jawab atasan (Superior Responsibility), hal mana yang menjadi subyek dalam huruf b Pasal dimaksud adalah bukan komandan militer, melainkan para Penguasa Sipil dan/atau pimpinan - pimpinan, seperti Kepala Negara, Perdana Menteri, Menteri dan unsur - unsur lainnya dari kalangan sipil.

Pada prinsipnya unsur dari Tanggung jawab Komando sebagaimana yang diatur dalam Pasal 28 huruf a, ialah harus memuat unsur kekuasaan dan kendali yang efektif dari Komandan atau atasan, kegagalan Komandan dalam melakukan Pengendalian dengan baik, mengetahui atau seharusnya mengetahui kejahatan yang akan atau sedang dilakukan oleh anak buah atau pasukannya, unsur kegagalan dan/atau tidak berhasil dalam mengambil semua tindakan yang diperlukan untuk mencegah terjadinya kejahatan atau menindak kejahatan (tindakan Preventif dan Represif).

Sedangkan dalam Pasal 28 huruf B, harus memuat unsur kekuasaan dan kendali yang efektif dari Komandan atau atasan, kegagalan atasan dalam melakukan Pengendalian, atasan mengetahui atau secara sadar mengabaikan informasi tentang kejahatan yang akan atau sedang dilakukan oleh anak buah, tidak berhasil dalam mengambil semua tindakan yang diperlukan untuk mencegah terjadinya kejahatan atau menindak kejahatan (tindakan Preventif dan Represif).

Jika dianalisa dengan poin pembahasan pertama tentang pengertian pertanggungjawaban komando dalam lingkup hukum internasional, dapat disimpulkan bahwa tanggung jawab komandan atau atasan, didasarkan atas kegagalan komandan dan/atau atasan dalam mengendalikan anak buah atau pasukannya yang melakukan kejahatan, hal mana komandan atau atasan dimaksud telah mengetahui atau sepatutnya mengetahui pasukan atau bawahannya akan, sedang atau telah melakukan kejahatan. Selain daripada itu juga, konsep tanggung jawab ini juga didasarkan atas ketidakberhasilan komandan dan/atau atasan dalam melakukan pencegahan dan tindakan penuntutan terhadap kejahatan yang dilakukan oleh anak buahnya.

Pemberlakuan prinsip pertanggungjawaban komando dalam beberapa ketentuan hukum internasional adalah untuk memperluas konsep pertanggungjawaban individu yang didakwa melakukan kejahatan internasional, dengan demikian pendakwaan terhadap pelaku kejahatan menjadi tidak terbatas, artinya tidak hanya pelaku secara langsung (anak buah) saja yang bisa mempertanggungjawabkan perbuatannya melainkan pimpinan atau komandanpun dapat mempertanggungjawabkan perbuatan anak buahnya, sekalipun komandan dimaksud tidak terlibat dalam melakukan kejahatan dimaksud. Aspek ini adalah salah satu berntuk pengaplikasian penegakan hukum pelaku kejahatan sebagai tujuan dari keseluruhan instrumen hukum internasional di atas.

Pemberlakukan Konsep atau Doktrin pertanggungjawaban komando yang didasarkan atas kegagalan komandan/atasan dalam mengendalikan anak buahnya yang akan atau sedang melakukan kejahatan berat HAM yang tercantum dalam ketentuan - ketentuan hukum internasional sebagaimana yang telah dijelaskan di atas, dapat ditafsirkan sebagai berikut: bahwa walaupun sebelumnya komandan atau atasan telah melakukan upaya pengendalian (Pencegahan dan tindakan) terhadap anak buahnya namun upaya yang telah dilakukan tersebut tetap dianggap gagal, maka sikap komandan atau atasan dimaksud dapat dipertanggungjawabkan secara pidana. Jika prinsip pertanggungjawaban komando ditafsirkan seperti itu, maka menurut hemat penulis konsep dimaksud kuranglah adil apabila sikap komandan atau atasan tersebut dipertanggungjawabkan secara pidana, karena setidak - tidaknya komandan atau atasan dimaksud sebelumnya telah berusaha untuk mengendalikan anak buahnya.

Namun Konsep Pertanggungjawaban Komando dalam ketentuan - ketentuan hukum internasional ini, disisi lain juga dapat ditafsirkan sebagai berikut: bahwa kegagalan komandan atau atasan dalam mengendalikan anak buahnya dapat dikatakan sebagai tindakan pembiaran (ommision), artinya komandan atau atasan sama sekali tidak melakukan upaya pengendalian (Pencegahan atau tindakan) terhadap bawahan atau anak buahnya, sehingga atas dasar hal itu, komandan atau atasannya tersebut dapat dipertanggungjawabkan secara pidana. Jika konsep pertanggungjawaban komando dalam Pasal ini ditafsirkan seperti itu maka menurut hemat penulis konsep dimaksud sudahlah sangat adil, karena seyogyanya seorang komandan atau atasan, wajib melakukan upaya 
pengendalian terhadap anak buahnya, sekalipun dalam upaya pengendalian tersebut masih tetap tidak membuahkan hasil.

Penafsiran tentang pertanggungjawaban komando yang didasarkan atas komandan/atasan yang gagal dan/atau sama sekali tidak melakukan upaya pengendalian (pencegahan atau tindakan) terhadap anak buahnya, juga dapat ditemui dalam hukum domestik di negara Indonesia yang termuat dalam pasal 42 ayat 1 dan 2 Undang - Undang Nomor 26 tahun 2000 tentang Pengadilan Hak Asasi Manusia, yang pada hakikatnya menyatakan sebagai berikut: ${ }^{21}$

1. Komandan militer atau seseorang yang secara efektif bertindak sebagai komandan militer dapat dipertanggungjawabkan terhadap tindak pidana yang berada di dalam yurisdiksi Pengadilan HAM, yang dilakukan oleh pasukan yang berada di bawah komando dan pengendaliannya yang efektif, atau di bawah kekuasaan dan pengendaliannya yang efektif dan tindak pidana tersebut merupakan akibat dari tidak dilakukan pengendalian pasukan secara patut, yaitu:

a. komandan militer atau seseorang tersebut mengetahui atau atas dasar keadaan saat itu seharusnya mengetahui bahwa pasukan tersebut sedang melakukan atau baru saja melakukan pelanggaran hak asasi manusia yang berat; dan

b. komandan militer atau seseorang tersebut tidak melakukan tindakan yang layak dan diperlukan dalam ruang lingkup kekuasaannya untuk mencagah atau menghentikan perbuatan tersebut atau menyerahkan pelakunya kepada pejabat yang berwenang untuk dilakukan penyelidikan, penyidikan, dan penuntutan.

2. Seorang atasan, baik polisi maupun sipil lainnya, bertanggungjawab secara pidana terhadap pelanggaran hak asasi manusia yang berat yang dilakukan oleh bawahannya yang berada di bawah kekuasaan dan pengendaliannya yang efektif, karena atasan tersebut tidak melakukan pengendalian terhadap bawahannya secara patut dan benar, yakni:

a. atasan tersebut mengetahui atau secara sadar mengabaikan informasi yang secara jelas menunjukkan bahwa bawahan sedang melakukan atau baru saja melakukan pelanggaran hak asasi manusia yang berat; dan

b. atasan tersebut tidak mengambil tindakan yang layak dan diperlukan dalam ruang lingkup kewenangannya untuk mencegah atau menghentikan perbuatan tersebut atau menyerahkan pelakunya kepada pejabat yang berwenang untuk dilakukan penyelidikan, penyidikan, dan penuntutan.

Berdasarkan hal tersebut, maka Pasal dalam ketentuan Pengadilan HAM dimaksud juga termasuk ke dalam konsep atau prinsip pertanggungjawaban komando menurut hukum internasional yang didasarkan pada sikap komandan atau atasan yang telah gagal dan/atau sama sekali tidak melakukan upaya pengendalian berupa pencegahan atau tindakan terhadap anak buahnya.

Salah satu contoh kasus atau perkara pemberlakukan prinsip Pertanggungjawaban Komando atas Kejahatan berat HAM dalam skala Internasional adalah dalam kasus Jenderal Tomoyoki Yamashita, Komandan Jenderal Group AD ke-14 dari Tentara Kerajaan Jepang dan sekaligus menjabat sebagai Gubernur militer di Philipina dipersalahkan karena secara melawan hukum telah mengabaikan dalam melaksanakan tugasnya sebagai komandan untuk mengendalikan operasi pasukan yang berada di bawah komandonya, membiarkan pasukannya melakukan pembunuhan brutal dan kejahatan serius lainnya terhadap warga Amerika Serikat dan Philipina, sekutunya dan keluarga mereka. ${ }^{22}$

Putusan pengadilan kejahatan perang terhadap Jendaeral Tomoyuki Yamashita pasca Perang Dunia II telah meletakkan prinsip tanggung jawab komandan terhadap pelanggaran hukum perang atau kejahatan perang. Komandan harus bertanggung jawab atas tindakan anak buahnya jika terpenuhi unsur-unsur:

1. Komandan mengetahui anak buahnya akan melakukan suatu kejahatan perang tetapi ia tidak mencegahnya.

\footnotetext{
${ }^{21}$ Pasal 42 Undang - Undang Nomor 26 tahun 2000 tentang Pengadilan Hak Asasi Manusia

${ }^{22}$ Burhan Dahlan, Op.Cit.,
} 
2. Komandan mengetahui anak buahnya telah melakukan suatu kejahatan perang tetapi ia tidak menghukumnya.

3. Komandan seharusnya mengetahui anak buahnya akan melakukan suatu kejahatan perang tetapi ia tidak mencegahnya.

4. Komandan seharus mengetahui anak buahnya telah melakukan suatu kejahatan perang tetapi ia tidak menghukumnya.

Pada dasarnya penulis setuju dengan adanya pemberlakuan tanggung jawab komando, dengan catatan bahwa pemberlakukan tanggung jawab dimaksud didasarkan atas komandan yang sama sekali tidak melakukan upaya pengendalian berupa pencegahan atau tindakan terhadap anak buahnya. Namun penulis kurang setuju jika pemberlakuan tanggung jawab komando dimaksud didasarkan atas ketidakberhasilan upaya pengendalian yang sebelumnya telah dilakukan komandan atau atasan terhadap anak buahnya. Hal itu kuranglah adil, karena sebelumnya komandan atau atasan tersebut setidak - tidaknya telah beritikad baik melakukan upaya pencegahan/pengendalian atas perbuatan anak buahnya (walaupun usaha pengendaliannya tersebut tidak membuahkan hasil).

Berdasarkan hal itu, maka perlu adanya pembatasan dalam pemberlakuan konsep dan/atau Doktrin tanggung jawab komando ini, sehingga kemudian tidak selamanya komandan atau atasan dapat dipertanggungjawabkan atas perbuatan anak buahnya, mengingat jika komandan atau atasan dimaksud sebelumnya telah beritikad baik melakukan upaya pengendalian terhadap anak buahnya yang akan atau sedang melakukan kejahatan.

\section{PENUTUP}

\section{A. Kesimpulan}

1. Konsep pertanggungjawaban komando, mempunyai makna yang sangat luas, artinya konsep ini tidak terbatas dan berlaku bagi setiap pemangku jabatan dan/atau setiap atasan yang mempunyai kendali atas anak buahnya, sekalipun itu adalah kepala negara, kepala pemerintahan, menteri, pimpinan militer maupun pimpinan perusahaan. Kesemuanya dibebani tanggungjawab atas perbuatan yang dilakukan oleh anak buahnya. Dalam praktek dan perkembangannya, doktrin tanggung jawab komando bukan hanya diberlakukan para komandan militer saja tetapi juga diperuntukan terhadap atasan atau penguasa sipil yang memiliki kewenangan untuk memberikan komando atau perintah kepada pejabat militer atau menggerakkan kekuatan militer. Kejahatan berat HAM merupakan kejahatan yang mempunyai kualitas kejahatan yang sangat tinggi dan mempunyai dampak buruk bahkan berdampak luar biasa dahsyat terhadap jiwa, raga, dan peradaban manusia, selain daripada itu dalam berbagai kasus yang ditemui, kejahatan berat HAM biasanya dilakukan sebagai alat bagi pencapaian dari kebijakan-kebijakan pemerintah. Kejahatan berat HAM yang dikategorikan dalam skala Internasional yang dihimpun dalam beberapa Instrumen Hukum Internasional terbagi ke dalam 4 Kategori yakni: Kejahatan terhadap perdamaian yang didalamnya memuat kejahatan agresi, Kejahatan Genosida, Kejahatan terhadap kemanusiaan, dan kejahatan perang.

2. Doktrin Pertanggungjawaban komando atas Kejahatan berat HAM dalam skala Internasional ini mempunyai penafsiran yang sangat luas, salah satunya dapat ditafsirkan bahwa walaupun sebelumnya komandan atau atasan telah melakukan upaya pengendalian (Pencegahan dan tindakan) terhadap anak buahnya namun upaya yang telah dilakukan tersebut tetap dianggap gagal, maka sikap komandan atau atasan dimaksud dapat dipertanggungjawabkan secara pidana. prinsip pertanggungjawaban komando tersebut diniali kurang adil apabila sikap komandan atau atasan tersebut dipertanggungjawabkan secara pidana, karena setidak - tidaknya komandan atau atasan dimaksud sebelumnya telah berusaha untuk mengendalikan anak buahnya. Namun Doktrin Pertanggungjawaban ini, disisi lain juga dapat ditafsirkan bahwa kegagalan komandan atau atasan dalam mengendalikan anak buahnya dapat dikatakan sebagai tindakan pembiaran (ommision), artinya komandan atau atasan sama sekali tidak melakukan upaya pengendalian (Pencegahan atau tindakan) terhadap bawahan atau anak buahnya, sehingga atas 
dasar hal itu, komandan atau atasannya tersebut dapat dipertanggungjawabkan secara pidana. konsep pertanggungjawaban komando dalam Pasal ini dinilai adil, karena seyogyanya seorang komandan atau atasan, wajib melakukan upaya pengendalian terhadap anak buahnya, sekalipun dalam upaya pengendalian tersebut masih tetap tidak membuahkan hasil.

\section{B. Saran}

Bahwa sebaiknya dalam menentukan suatu ketentuan khususnya dalam instrumen ketentuan hukum pidana internasional, wajib disebutkan secara tegas tentang doktrin pertanggungjawaban komando ini, karena pada hakikatnya unsur yang harus dipenuhi dalam kententuan dimaksud adalah akibat dari gagalnya dan/atau tidak berhasilnya komandan dalam mengendalikan anak buahnya yang akan, sedang atau telah melakukan kejahatan Internasional (Kejahatan berat HAM). Penafsiran pertama, Redaksi frasa "gagal" dapat ditafsirkan sebagai upaya atau tindakan pengendalian yang sebelumnya telah dilakukan oleh komandan atau atasan terhadap anak buahnya, namun upaya yang dilakukannya tersebut tetap tidak berhasil dan tidak membuahkan hasil, karena pada akhirnya anak buah tetap berbuat diluar kendali dari komandan atau atasannya. Penafsiran kedua, redaksi frasa "gagal" ini dapat juga ditafsirkan sebagai perilaku komandan yang sama sekali tidak melakukan pengendalian apapun terhadap anak buahnya yang akan atau sedang melakukan kejahatan sehingga dapat dipersamakan sebagai tindakan pembiaran (ommision).

Menurut penulis persoalan itulah yang mungkin harus lebih diperjelas dan dipertegas lagi dalam ketentuan - ketentuan hukum pidana internasional, karena hal itu akan sangat berhubungan dengan rasa keadilan para pihak - pihak yang terkait khususnya korban, masyarakat dan para penegak hukum.

\section{REFERENSI}

\section{Buku/Textbook:}

Andrey Sujatmoko,Tanggung Jawab Negara atas Pelanggaran Berat Hak Asasi Manusia. Indonesia, Timor Leste, dan lainnya, Gramedia Widiasarana Indonesia, 2005

Cecilia MedinaQuiroga, The battle of Human Rights; Gross, Systematic Violation and the inter American system, Dordrech/Boston/London: Martinus Nijhoff Publishers, 1988

Eddy Djunaedi Karnasudirdja, dari Pengadilan Militer Internasional Nuremberg ke Pengadilan Hak Asasi Manusia Indonesia, Jakarta, Tatanusa, 2003.

2003.

Romli Atmasasmita, Pengantar Hukum Pidana Internasional, Bandung: Refika Aditama, , Hukum Pidana Internasional dalam rangka perdamaian dan kemanan Internasional, Jakarta: Fikahati Aneska, 2010.

\section{Jurnal \& Penulisan Hukum :}

Burhan Dahlan, Tanggung Jawab Komando dalam Hukum Humaniter Internasional, Penulisan Hukum, 2011.

ELSAM, Makalah Tanggung Jawab Komando.

Fadillah Agus, makalah Tanggungjawab Komando, dalam Seminar "Judging international Crimes under law 26/2000, Mahkamah Agung RI-Danish Institute for human Rights, Medan 24 - 26 April 2005

Hidayat Muhtar, dalam Penulisan hukum, Kajian Yuridis terhadap Asas Pertanggungjawaban Komando.

International Law Commision, Draft Article on Responsibility of statesfor Internationally Wrongful Act Adopted by the drafting Committee on Second Reading, Geneva 2001.

Natsri Anshari, Dalam Artikel Tanggung Jawab Komando Menurut Hukum Internasional dan hukum nasional Indonesia, Jurnal Hukum Humaniter Vol.1 No.1, Pusat Studi Hukum Humaniter Dan HAM (terAS) Fakultas Hukum Universitas TRISAKTI, 2005. 
Sihombing, Perintah Atasan dan pertanggungjawaban Komando dalam Kejahatan Perang, "Problematika Kejahatan Perang dalam hukum Pidana Indonesia", Bandung: Pusat kajian HAM dan Hukum Humaniter UNISBA-The International Committee of The Red Cross (ICRC), 2005.

Vonny A Wongkar, Tanggung Jawab Komando terhadap Pelanggaran Hak Asasi Manusia (HAM) yang berat dan Kejahatan Perang dalam Pembaharuan Hukum Pidana di Indonesia, Thesis, FH UNDIP, 2006.

Weston D. Burnett, Command Responsibility and Acase Study of the Criminal Responsibility of Israel Military Commanders for the Progrom at Shatila and Sabra, 107 Military Law Review, 1985.

\section{Undang - Undang/Konvensi/Treaty :}

Konvensi Den Haag 1907

Protokol tambahan I Konvensi jenewa 1949 dan 1977

Statuta Roma tahun 1998 tentang Mahkamah Pidana Internasional

Undang - Undang Nomor 26 tahun 2000 tentang Pengadilan Hak Asasi Manusia

Piagam Peradilan Militer Internasional Nuremberg.

\section{Internet :}

www.google.co.id

www.eprints.undip.ac.id/15338/1/

Penulisan Hukum tentang Pengaturan Pelanggaran Kejahatan HAM Berat Menurut Hukum

Internasional dalam http://repository.usu.ac.id/bitstream/123456789/48857/3/Chapter\%20II.pdf 